\title{
Implementing Value Clarification Technique to Improve Environmental Awareness among Pre- Service Chemistry Teacher
}

\author{
Sulastri, D. Budimansyah, W. Sopandi \\ Values Education School of Post Graduate \\ Science Education School of Post Graduate \\ Universitas Pendidikan Indonesia \\ budimansyah@upi.edu
}

\begin{abstract}
This research aimed at describing the implementation of value clarification technique combined with problem based learning and project based learning in basic chemistry course for organic chemistry topics. The subjects of this study were all students of Preservice chemistry teacher from Chemistry Education Study Program of Teacher Training and Education Faculty of Universitas Syiah Kuala in Indonesia. They were at even semester in 2014-2015. They learned by problem and project based learning and implemented values by choosing, prizing and acting topics of organic in daily life. To collect data used field notes, documentation, questionnaires and a portfolio report. To analysis data used qualitative method as collection, reduction, presentation data and conclusion. The research conclusions were, learning organic chemistry by integrating project based learning and problem based learning strategies with value clarification technique could be applied in chemistry learning. Students become able to clarify the human value in nature with regard to most of the topics they have studied in organic chemistry. Based on the findings, this study recommended that the innovative learning strategies such as project based learning, problem based learning combining with value clarification technique, could be adopted in chemistry education courses to increase environmental awareness of pre-service chemistry teacher.
\end{abstract}

Keywords-value clarification technique; pre-service teacher; environmental awareness; organic chemistry

\section{INTRODUCTION}

Modern society cannot be separated from a variety of industrial products for food-beverage, clothing, housing, transportation, communication, household materials, cosmetics, medicines and so on. All materials in the production activities of our needs always produce waste that can pollute the environment, and also always generate waste when we use it. It is increasingly made the earth to be miserable.

All inhabitants of the earth need to take special time and a serious concern for an active role to preserve the universe. For the survival of future generations requires the quality of clean oxygen; eating foods that are healthy and nutritious, free from pollution from pesticides, herbicides, preservatives and chemicals other additives that are not safe for the body; drinking water that is free from contaminants; can grow, live and carry out activities of life in a healthy and safe environment; can hear the chirping of birds and enjoy the beauty of nature. Thus, anyone should not be put off to have an awareness of protecting the environment.

[1] The UNESCO-the United Nations Environment Programme (UNEP) International Environmental Education Programme (IEEP) take the role seriously by doing a number of meetings to discuss the problem of the environment until it finally emphasizes that it is important to develop a corresponding teaching material to develop values education environment for learners at all levels of education to be carried out in the school or outside of school. This statement is reinforced by research [2], and [3] that environmental education syllabus at all education levels, both formal and informal, should be prepared to help achieve environmental awareness. Moreover, the results of other research also support, that [4] Consciousness to keep the environment has not been a priority in developing countries. In Southeast Asia, such as Indonesia and Malaysia environmental awareness of its citizens still low [5]. Environmental awareness Gap neighbourhoods still high [2]. Things that are not different also occurred in Indonesia. [6], Indonesia Ministry of Environment (MoE) reported survey results 2013 against the inhabitants of Indonesia represented all elements of the community conducted by the ministries of the environment, found only $2.5 \%$ of the respondents who obtain information about the environment through education at school. This means that the school has not taken a serious role for developing environmental awareness in students. Sulastri [7], found pre-service chemistry teachers did not yet have good environmental awareness. Ideally chemistry teacher candidates need to have a good environmental awareness, as almost all environmental pollutants derived from chemicals. In lectures they have learned about the basic concepts of 
hydrocarbons, petroleum refining, burning fuel, plastic polymers, alkyl halides, aldehydes, ketones, carboxylic acids, esters and macromolecular compounds. All chemicals were studied have potential as environmental pollutants.

Teachers need to have the knowledge, attitude and behaviour towards the environment so that teachers become role models for learners to protecting the environment. Attitudes and behaviour is formed through conditioning and training. For that student teachers need to be reinforced with educational value that can develop environmental awareness. [8], has stated that in order to develop good character values through three stages, namely moral knowing, moral feeling and moral action. Learn chemistry concepts that have been experienced by the students to develop cognitive skill. Teachers need to have cognitive insight, attitudes and corresponding behaviors. Education for prospective teachers need to cultivate their moral knowing, develop moral feelings and train them to have a good moral action. Therefore lectures to prospective teachers need to develop moral feeling and familiarize moral action through a combination of learning concepts with the application of problem-based learning (PBL), combined with the application in everyday activities through project-based learning (PjBL) followed by learning the value clarification technique (VCT), so that the student is able to choose the values are good in protecting the environment, declaring the values that have been in protecting the environment to other people to be emulated by others and they also define the ways they maintain values have been a regular habit in the daily life activities. Problem base learning is effective for increasing mastery of chemical concepts, improving the interaction among students, improve communication skills, develop self-learning ability and increase the confidence of students [9], [10], [11], [12], and [13]. Project-based learning has a positive influence to develop soft skills and got a positive response from students of chemistry [14]. The other hand, PjBL will familiarize students to conduct an investigation that is believed to improve the quality of education. PjBL also will enable student learning, enabling students to be innovative and creative to transfer their knowledge to real-world situations [15] and [16].

According to [17], he has recommended that educational strategies such values clarification technique is more effective in promoting the value of learning achievement of cognitive and affective aspects in environmental education. This is supported by [18]. He found that the values clarification technique is an effective model for cultivating the values chosen [17].

Value clarification technique has been developed by Raths, Harmin and Simon. VCT is composed of seven sub-processes that can be grouped into three categories. Its categories are choosing value, prizing values and acting values. Sub processes in each category are: (1) choosing freely, (2) choosing from alternatives, (3) after thoughtful consideration of the consequences of each alternative. There are two sub-processes in prizing categories, namely (4) respect, feeling happy with the choice, (5) is willing to assert the public option. Finally, the third category is acting. Inside there are two sub- processes, namely (6) to do something with the choice, (7) do repeatedly with several patterns in everyday life. These processes collectively determine valuing. Results of the judging process called values [19].

\section{RESEARCH METHODS}

The aim of this study was to describe the implementation of the basic chemistry lectures on the topic of organic chemistry with values clarification techniques combined with problem-based learning and project-based learning to develop the environmental awareness of pre-service chemistry teacher.

This research was conducted at the pre-service chemistry teacher student of chemistry study program of teacher training and education faculty of Universitas Syiah Kuala Banda Aceh Indonesia. All first-year students in the second semester of 2014-2015 academic years were involved in this study. They consist of 9 male students and 38 female students. They have followed the basic chemistry lectures on the topic of organic chemistry for three weeks by using model problem based learning.

Preparation conditions of the students before the lectures were conducted in this study were (1) one week before lectures began to students were briefed on VCT, such as explaining what did VCT mean, what were the purposes of the lecture, what we're learning activities to be performed by students in lectures, what were tasks they have to do during the lecture and after the lecture took place, how did they report their learning progress. Finally, the students are given the format of the project activity reports, this report must be returned one month after completion of the learning activities.

Lecturing activities have been carried out for three weeks through problem based learning with discussion method. The purpose of the lecture is to strengthen the knowledge of the concepts of organic chemistry. All knowledge about the concepts of organic chemistry is always associated with a broader perspective on the effects of chemicals are studied on the environment and the health of living beings. At any lectures they have had discussions and they have presented the results of the discussion. Lecturers have always reminded students to observe the phenomenon of the use of organic chemicals that they have learned in everyday life. They have done project-based learning to focus on choosing organic chemicals as they like. The selection is done independently of the number of alternatives that exist. They declare their choice to others, such as family, neighbors or their friends as steps as described by Raths et al [19]. They apply the values that support the safety of the environment in the use of chemicals. They have to get used to act, behave according to the value they have chosen. All of the activities they have done are recorded in the statement of values clarification project that has been given to them before the lecture done. They were given the opportunity to carry out the activities for one month. Finally, one month later the students' reports were collected to be analyzed by the researchers. All of students' activities are recorded for becoming the supporting data in the data analysis. At the end of each meeting, the students always provide feedback to the learning process they experienced. 


\section{RESULTS AND DISCUSSION}

\section{A. Learning Activities.}

At the first meeting, lecture activities not performing as expected. Many students have not prepared well for following the lecture. Most of the students had not read the books recommended mandatory and only the one-fifth of the student who carried textbooks. They could no longer activate in the discussion. Most of the existing problems should be helped solving the problem by the lecturer Overcoming this fact, thirty minutes before the completion of lectures, lecturer used the time to motivate the students, stimulated them to learn seriously. Unresolved issue in the first meeting, served as a homework assignment. Lecturer has been provided additional time outside of lectures to discuss with the students that they have actually able to solve problems on a topic that should they learned. This problem also found by others researchers [9], and [10].

In the second week of the course, the students are already heavily involved in group discussions. They have been actively asked and answered the questions. They have dared to present to perform in class discussions. Almost all students have been brought and read textbooks are recommended. This condition continues to get better at the next meeting.

\section{B. Reflection On Learning .}

According to the students' reflection, researchers found that as many as $85.6 \%$ of the students stated that they have had the pleasure of learning with a model that is applied. The application of this learning has been a new experience for them. Problem-based learning has made them understand the concept of organic chemistry. Learning with project based learning has given them the opportunity to train themselves independently to practice the knowledge they have learned in everyday life with full planning. This activity has made them realize the importance of protecting the environment. Learning with VCT has made them the ability to have the freedom to choose the values they think are important to their practice with good moral considerations. Learning activities in the classroom has been able to increase their interaction with their peers in the group, has been able to make them more confident and more willing to ask questions about things they know are not clear in the lecture. Their recognition, this study has made them become better understood and has to involve them actively in the lecture even though at the beginning of the course they are not happy with the rules of the course because they are not familiar with this kind of learning. They expressed wish to emulate the model of learning that they have experienced in learning that they will do later when they become teachers.

Other findings, is $76 \%$ of the students said they had become like studying organic chemistry. Elsewhere, it was reported in [20], He found that organic chemistry is a difficult subject and not liked by students. In this study, the combination of learning concepts of organic chemistry with learning the value of environmental awareness has been able to change the mind set of students. Organic chemistry became favored subjects, as found by Metaka [11]. This finding is reinforced by [Lovat], He stated that learning is enriched by the values can make the knowledge, attitudes and behavior to be better together.
Learning like this is called a double helix effect of value education.

\section{Value Clarification}

After learning process as steps of value clarification technique by choosing, prizing and acting, they clarified things as shown in table I.

TABLE I.

Phenomena that Chosen by Students

\begin{tabular}{lll}
\hline No & Preferred phenomenon & $\begin{array}{l}\text { Amount of } \\
\text { students }\end{array}$ \\
\hline 1 & Air pollution by vehicles emission & 11 \\
2 & Plastic waste & 7 \\
3 & Global warming and climate change & 5 \\
4 & The vehicles usage & 4 \\
5 & Developing research to find solutions to & 3 \\
& environmental problems & \\
6 & Alternative energy source & 2 \\
7 & Borax usage & 2 \\
8 & The separation of organic and inorganic waste & 2 \\
9 & Paperless & 1 \\
10 & Mercury waste & 1 \\
11 & Water pollution & 1 \\
12 & Household waste & 1 \\
13 & Utilization of waste cooking oil & 1 \\
14 & Sanitary napkins & 1 \\
15 & Utilization of wipes & 1 \\
16 & Burning used tires & 1 \\
17 & Cosmetics Dangerous & 1 \\
18 & Artificial sweeteners & 1 \\
19 & Cigarette & 1 \\
& & \\
Total amount & 47 \\
\hline & &
\end{tabular}

There was some organic chemical material that has been discussed in the lecture but none of who choose these phenomena to be clarified. They were herbicide and pesticide, persistent organics pollutants and cooling materials as refrigerants.

Based on values clarification project reports compiled after the analysis can be identified values that develop in students. Referring to the 10 core primary virtue [8], [21], could be identified value of the characters that appear in the students' VCT activities are as follows:: (1) the wisdom, values contained therein: good judgment, knowledge and ability on how to practice the values of kindness; ability to set priorities; (2) fairness: fairness, respect, responsibility, honesty and tolerance; (3) fortitude: courage, patience, perseverance, endurance, self-confidence; (4) self-control: self-discipline, the ability to manage emotions and impulses of the self, to delay gratification or not quickly satisfied ourselves, to resist temptation, (5) love: empath, compassion, kindness, generosity, service, patriotism; (6) a positive attitude: hope, enthusiasm; (7) the hard works: initiative, diligence, good setting, resourcefulness; (8) integrity: adhering to the moral principle faithfulness to a well-formed conscience, correctly keeping one's word, an ethical consistency, being honest with oneself; (9) gratitude: acknowledging one's debts to others; (10) humility: self-awareness, willingness to mistakes and responsibility to them, and the desire to become a better person.

\section{CONCLUSION}

Value clarification technique can be applied in organic chemistry lecture. Combination of problem based learning, project based learning and VCT has been applied 
in organic chemistry lecture. Problem-based learning is applied to achieve cognitive skill. Project-based learning is applied to provide training opportunities to develop character values associated environmental awareness, especially in the use of organic chemicals in everyday life. They started to get used to utilizing organic chemicals that are environmentally friendly. They are concerned about air pollution, plastic waste, global warming and climate change, the vehicle usage, developing research to find environmental problems solutions, source of alternative energy, additive food like borax, separation of organic and in-organic waste, paperless, handling mercury waste from public miner, water pollution, household waste, utilization of waste cooking oil uncontrolled, sanitary napkins, wipes waste, burning waste uncontrolled, dangerous cosmetics, using artificial sweetener uncontrolled, cigarette. Almost all the characters contained in ten goodness values that have been declared by Lickona [8] can be developed in this study. This approach is also very well received by students. After learning process their environmental awareness be better. They have had wise moral considerations in choosing and acting against many phenomena that occur in everyday life related to organic chemicals that have been studied with regard to the environment. Learning that has done this to make students into the lecture topics enjoys organic chemistry. Learning experiences they have experienced are also able to increase the activity of learning, interaction and better communication skills in students

\section{REFERENCES}

[1] Caduto, M. J. "A Guide on Environmental Values Education", Paris, UNESCO. 1985.

[2] Aminrad Z, Sharifah Z. Bt S. Z., Abdul S.H., and Sakari, M. "Environmental Education In Malaysia, Progresses and Challenges Ahead", Life Sci J, 2012, 9(2): 1149-1154. http://www.lifesciencesite.com (13 Agustus 2015).

[3] Ugulu, I., Sahin, M., and Suleyman B. "High School Students' Environmental Attitude: Scale Development and Validation", Int J Edu Sci, 2013, 5(4): 415-424

[4] Li, J.C. "Environmental Impact Assesments in Developing Countries: An Opportunity for Greater Environmental Security?" Working paper No. 4, Foundation for Environmental Security \&Susrtaiablity, USAID, 2008.

[5] Karpudewan, M., Zuraida I., and Norita M. "Pre-Service Teachers' Understanding and Awareness of Sustainable Development Concepts and Traditional Environmental Concepts, Asia pacific Journal of Educators and Education, 28: 117-130. 2013
[6] Indonesia Ministry of environmental. Survey report on Environmental Care Behavior Index, 2013. sirusa.bps.go.id/sirusa/index.php/.../view?kd...(30 October 2013).

[7] Sulastri., Budimansyah, D., and Sopandi, W. "Environmental Awareness of Pre-Service Chemistry Teachers In Aceh". In Proceedings of the 6th International Conference On Teacher The Standardization of Teacher Education Asian Qualification Framework., 2014. pp. 868-882.

[8] Lickona, T. "Educating for Character; How Our Schools Can Teach Respect And Responsibility". New York. Bantam Books. 1991.

[9] Okinoglu, O. Rohan O.T. "The Effect of problem Based Active Learning in Science Education on Students' Academic Achievement, Attitude and Concept Leraning", Eurasio Juornal of Mathematics, Science \& Technology Education, 2007, 3(1), 7181.

[10] Akcay, B., " problem Based Learning in Science education"” Journal of Turkish Science Education, 2009, 6(1), 26-36.

[11] Mataka, L.M.P, "Problem Based Leraning in The College Chemistry Laboratory: Students' Perceptions of PBL and Its Relationship with Attitude and Self Efficacy Belief (Dissertation)", Mallinson Institute for Science Education, Western Michigan University, 2014.

[12] Tsankov, N.S. "Students' Motivations in The Process of ProblemBased Education in Chemistry and Environmental Sciences", International Journal of Humanities \& Social Science, 2012, 2(21), 155-156.

[13] Hmelo-Silver, C.E., Ravit G.D. and Clark A. C., "Scaffolding and Achievement in Problem-Based and Inquiry Learning: A Response to Kirschner, Sweller, and Clark (2006), Educational Psychologist, 2007, 42(2), 99-107.

[14] Sumarti, S.S., Wuryandini, Sudarmini, "Project Based Learning Model Development on Buffer Solution Materials with Soft Skill Enterpreneur Oriented, IJES, 2015, 4(3), 5-10.

[15] Sumarni, W., "Implementation of Project Based Learning: a Review", International Journal od Science and Research (IJSR), 2015, 4(3), 478-484.

[16] Bell, S., "Project Based Learning for 21-st Century: Skill for the Future", The Clearing House, 2010, 83(2), 39-43.

[17] Ogunbiyi, J.O. and Ajiboye, J.O. "Pre-service Teachers' Knowledge of and Attitudes to Some Environmental Education Concepts using Value Education Strategies", Anthropologist, 2009, 11 (4): 293-301.

[18] Rai, R., "Comparative Effectiveness of Value Clarification and Role Playing Value Development Models for Selected Values for Primary School Students", IOSR Journal Of Humanities And Social Science (IOSR-JHSS), 2014, 19 (1-I), 28-34.

[19] Raths, L. E., Harmin, M., and Simon, S.B. "Values and Teaching: Working with Values in the Classroom", Charles F. Merril Publishing Company, Columbus, 1966

[20] [20] Kampmeier, J.A., dan Pratibha V. N. "Peer Led Team Learning: Organic Chemistry, Chemists'Guide to Effective Teaching", Vol. II, Prentice Hall, New Jersey, 122-145. 2009

[21] [21] Budimansyah, D., Yadi R., Nandang R. "Model Character Education in Higher Education: strengthening of civic education, Counseling Services and Education Thematic Work Experience at the University of Universitas Pendidikan Indonesia", UPI, Bandung, 2010 